Young L and Ansell N (2003) 'Fluid households, complex families: the impacts of children's migration as a response to HIVIAIDS in southern Africa' The Professional Geographer 55(4) 464-479

\title{
Fluid Households, Complex Families: The Impacts of Children’s Migration as a Response to HIV/AIDS in Southern Africa
}

\section{Lorraine Young and Nicola Ansell}

Brunel University

The fluidity of southern African families is related to a long history of internal and external migration. Currently, HIV/AIDS is having a dramatic impact on extended family structures, with the migration of individual members employed as a coping strategy. Children's migration is one aspect of this that is often distinct from that undertaken by other household members. This article is based on qualitative research conducted in Lesotho and Malawi with young migrants and the households that receive them. It examines the processes of fragmentation and re-formation of households through the movements of children that are taking place in response to HIV/AIDS, and explores the impacts these processes have on young migrants and the households they join.

Key words: children, fluid households, HIV/AIDS, migration, southern Africa.

\section{Introduction}

Southern Africa has a long history of internal and external migration. Mobility is considered to be one of the region’s essential and intrinsic features, without a comprehensive understanding of 
Young $L$ and Ansell N (2003) 'Fluid households, complex families: the impacts of children's migration as a response to HIVIAIDS in southern Africa' The Professional Geographer 55(4) 464-479

which societies and dynamics would be greatly misunderstood ("Mobility and Changing Sexual Behaviour” 1999). This is notable through the work of the Southern African Migration Project, which highlights the dispersal of families across space (Townsend 1997; McDonald 2000).

Migration of household members is often used as a coping strategy for the survival of the family. Migration was traditionally undertaken by men, who periodically left their homes in search of paid employment (Murray 1981; ILO 1998) — to work in the South African gold mines, for example (Crush et al. 1999). More recently, women’s migration has been noted, particularly in reference to cross-border migration from Lesotho to South Africa (Dodson 1998).

Mobility across southern Africa has also been discussed in relation to HIV/AIDS (Cliff and Smallman-Raynor 1992; BakamaNume 1996). Much of this literature has focused on the spread of the disease, highlighting the particular vulnerability of migrant populations due to the “social (and sexual) disruption that accompanies migration” (Williams et al. 2002, 7). More recently, research has considered how migration as a household coping strategy ${ }^{1}$ has been employed in response to the HIV/AIDS epidemic in southern Africa (UNAIDS 1999; Desmond, Michael, and Gow 2000). UNAIDS (1999) demonstrates that this is a response for raising household income to maintain expenditures on health care, with male members migrating in search of employment (McDowell and de Haan 1997). Interhousehold family re-allocation of both male and female members also occurs to alleviate loss of household labor and reduce any increased caring burden (UNAIDS 1999). Alternatively, members may be relocated to other households in the extended family for support, typically meeting basic needs (Sauerborn, Adams, and Hien 1996; Desmond, Michael, and Gow 2000). Children’s migration is often employed as one aspect of this (Ansell and Young 2002).

Nonetheless, children's migration has, to date, largely been unsatisfactorily subsumed 
Young L and Ansell N (2003) 'Fluid households, complex families: the impacts of children's migration as a response to HIVIAIDS in southern Africa' The Professional Geographer 55(4) 464-479

within family migration, although it is now accepted that children are social actors in their own right and sometimes migrate separately from other household members (Camacho 1999;

McKendrick 2001). Given this, it is inappropriate to conflate children's migration with family migration, as children often play an integral role in their extended families’ household survival strategies. This is especially true in southern Africa, where household and family structures are rapidly changing in light of the HIV/AIDS pandemic that is robbing many children of their parents and family-kinship groups (Grainger, Webb, and Elliott 2001).

This article examines the processes of fragmentation and re-forming of households through the movements of children that are taking place in response to HIV/AIDS. These movements, referred to here as “children’s migration,” are loosely defined to include all independent movements of children from their current resident household for a period longer than one month at the local, national, and international scales. ${ }^{2}$ Rather than focusing on AIDSrelated children's migration per se, however, this article outlines the reasons why it occurs and focuses, in particular, upon how the dispersal of family units affects children and the households they join. Through research undertaken in four locations in Malawi and Lesotho, the article explores the different ways in which children are incorporated into "new" households, the process and impacts of multiple moves, and the breakdown of relationships through sibling dispersal. Through this discussion, we suggest that AIDS-related children's migration is increasing the complexity of many households in southern Africa.

\section{Fluid Households: Complex Families}

"Household" and "family" are contentious terms when discussing domestic structures in southern Africa, as many societies exist in fluid ways, which results in constantly changing 
Young L and Ansell N (2003) 'Fluid households, complex families: the impacts of children's migration as a response to HIVIAIDS in southern Africa' The Professional Geographer 55(4) 464-479

forms, meanings, and relationships (Barnett and Whiteside 1999). Although "household” and "family" have been used interchangeably in some instances (Agarwal 1990), the dispersal of families across space due to labor migration renders this inappropriate for southern Africa, as family units may be divided among several households (Townsend 1997). ${ }^{3}$ Therefore, this article defines "household" as those who reside together and "extended family" as those who are bonded through kinship ties but whose members may—and often do—-live apart. Extended families may be split among several households, with membership constantly changing through individual migration.

The migration of household members as a strategy for increasing income and dealing with daily hardship does not involve only adult labor migration (Townsend 1997; Sporton, Thomas, and Morrison 1999). Children's movements play an integral role in household survival as they engage in unaccompanied employment-related migration. Boys are often sent to herd animals (Kimane and Mturi 2001), while girls may be sent to help in the homes of grandparents or recently married childless couples (Bandawe and Louw 1997). Others relocate to receive assistance from wealthier members of their extended family.

Historically, orphans often moved to live in their relatives’ households, as extended families undertook the burden of care (Munthali and Ali 2000). In patrilineal societies, such as those in Lesotho and central and northern Malawi, orphans "belong” to their father's brother and he takes responsibility for their care. In matrilineal societies, such as those found in southern Malawi, children "belong” to their mother’s line, and orphan care is the maternal uncle’s responsibility. Cultural practices have long since become fluid, however, with matrilineal and partilineal societies adopting each other’s practices (Chanock 1985; White 1987). This is particularly the case when marriage occurs between couples from different traditions, which has 
Young $L$ and Ansell N (2003) 'Fluid households, complex families: the impacts of children's migration as a response to HIVIAIDS in southern Africa' The Professional Geographer 55(4) 464-479

become increasingly common with migration (Ali 1998).

Although household boundaries have generally been fluid, the fragmentation and reforming process is becoming increasingly important as the dispersal of young household members is implemented as a coping mechanism in response to HIV/AIDS. The loss of productive labor through sickness and death has left many families in remnants, with depleted resources, facing the task of reconstructing productive households (Baylies 2001).

\section{Children's Migration and the Impact of AIDS}

Southern Africa is currently the region worst affected by HIV/AIDS (UNAIDS 2000). Recent statistics suggest that, respectively, 15 percent and 31 percent of Malawi and Lesotho adult populations are already infected (UNAIDS 2002). Occurring as a consequence of the associated rise in death toll (Urassa et al. 2001), household disintegration affects increasing numbers of children. Between 1994 and 1997, the number of AIDS orphans in Lesotho increased by 400 percent (UNICEF 1999), reaching a total of 73,000 then-currently living orphans by the end of 2001 (UNAIDS 2002). In Malawi, estimates of AIDS orphans have now reached 470,000 (UNAIDS 2002). ${ }^{4}$ As the ratio of children to healthy adults increases, it is mostly grandparents and children who find themselves re-forming households (Cohen 2000). Commonly, aging relatives are unable to provide the financial or physical resources to care for large numbers of children (Beer, Ross, and Tout 1988; Barnett and Blaikie 1992; Ntozi 1997), which may result in further household dispersal to ensure the survival of the wider extended family.

Children are affected, however, long before becoming orphans (UNAIDS, UNICEF, and BLCA 1999). They may be involved in household fragmentation because of their role as carers, in order to receive care, or to make a living. Elsbeth Robson (2000) discusses the caring role of 
Young L and Ansell N (2003) 'Fluid households, complex families: the impacts of children's migration as a response to HIVIAIDS in southern Africa' The Professional Geographer 55(4) 464-479

children—particularly girls—in Zimbabwean society. She highlights the fact that households often rely on extended family networks, mentioning young girls being sent to the city to care for sick relatives. Dispersal of household members may also occur following the death of a parent or if a parent wishes to return to the rural area when they fall sick.

The impact of AIDS on families and households in sub-Saharan Africa has been well documented (Barnett and Blaikie 1992; Cliff and Smallman-Raynor 1992; Webb 1997; Lyons 1999; Grainger, Webb, and Elliott 2001). Children's migration between households in response to HIV/AIDS is currently underresearched, however, although some evidence of its occurrence has recently emerged. For example, in Uganda, Mark Urassa and colleagues (1997) find that orphan and foster children are more often involved in migration than are other children, while in Zimbabwe, Geoff Foster and colleagues (1995) highlight rural-to-urban movements and suggest that children may also undertake urban-to-rural migration.

The dispersal of families across space has resulted in some children taking over the responsibility of caring for themselves and their siblings, because great distances between extended family members have resulted in the disruption of close ties to other households in the kin group. Foster and colleagues (1997) find that siblings sometimes prefer to stay together in familiar surroundings rather than move to live with relatives, fearing abuse, exploitation, and the loss of inheritance rights. In such circumstances, household dispersal may occur at a later stage, with poverty encouraging some children to take to the streets (Bourdillon 1999). Missing from these analyses is an understanding of why such migration occurs and of the implications for children who move of joining other households.

\section{Method}


Young L and Ansell N (2003) 'Fluid households, complex families: the impacts of children's migration as a response to HIVIAIDS in southern Africa' The Professional Geographer 55(4) 464-479

The research discussed here was conducted with young AIDS migrants and guardians in two southern African countries. In order to explore the impact of HIV/AIDS on children's role in household fragmentation and reconstruction in diverse situations, four communities were selected. Malawi was chosen due to its long-standing experience of HIV/AIDS, in contrast to the more recent but dramatic onset of the epidemic in Lesotho. In both countries, one urban and one rural community was selected in order to access a variety of experiences. ${ }^{5}$ The Malawi locations included Ndirande, a high-density township in Blantyre, the largest city, and Mpando village in Thyolo district, a major tea-growing area (Figure 1). In Lesotho, the research focused on Tlali village, in the foothills of the Maluti Mountains, and Maseru, the capital city, located on the border with South Africa (Figure 2).

Children-centered multimethod research, particularly the use of qualitative methods, was employed, drawing on methodologies developed by researchers exploring the impacts of migration on young people in other contexts (Camacho 1999; Jones 1993). Children aged 10 to 17 years $^{6}$ were accessed through four case-study schools by means of a brainstorming discussion on migration and a follow-up questionnaire. To identify young AIDS-affected migrants in this age, range questionnaires were distributed to 822 children in upper primary classes. ${ }^{7}$ In both rural schools, all children in these classes were asked to participate. The urban schools were much larger, and therefore the questionnaire was distributed to a random selection of classes, covering the same age range and involving a comparable number of children. [Au: what

\section{standards?]}

The questionnaire identified 296 children whose answers suggested that they might have engaged in AIDS-related migration ${ }^{8}$ or had other children move into their household. These children were then asked to participate in focus group discussions. In addition, and in order to 
Young L and Ansell N (2003) 'Fluid households, complex families: the impacts of children's migration as a response to HIVIAIDS in southern Africa' The Professional Geographer 55(4) 464-479

access the diverse range of migration experiences, focus groups were also conducted with children out of school residing in orphanages and living on the streets, accessed through local leaders and organizations. Following the discussions, sixty-five children who had voiced particularly interesting stories were invited to make migration storyboards on which they depicted their own migration experiences. The pictures acted as prompts for further discussion. These methods gave children the opportunity to express their views more freely and in greater detail.

Throughout the qualitative research, children revealed at least some knowledge of AIDS, but most did not know (or claimed not to know) the exact cause of their parents' death, merely describing symptoms and appearance of the patient. In the majority of cases, these symptoms were typical of those suffering from AIDS-related illness.

Within the surrounding communities, approximately forty guardians who had received children due to parental sickness or death took part in informal interviews. Guardians were selected with the help of local leaders and nongovernmental organization staff working in the area. The stigma associated with AIDS in both Lesotho and Malawi meant that people were reluctant to reveal their status or talk openly about the disease. Therefore, although most guardians attributed orphanhood and parental death in their communities to AIDS, this was not the case when they were discussing close family members.

The focus-group discussions, interviews, and storyboards that form the basis of this paper were coded to draw out the main themes highlighted by children and guardians. [Au: thus far you have not discussed any focus groups. Please provide a little detail on these groups, as you have done for the interviews and storyboards. - now mentioned earlier] The extracts used here are representative of the different experiences encountered. 
Young $L$ and Ansell N (2003) 'Fluid households, complex families: the impacts of children's migration as a response to HIVIAIDS in southern Africa' The Professional Geographer 55(4) 464-479

\section{Fragmenting Households: The Causes of Children's AIDS-Related Migration}

Amid the general fluidity of southern African families, children's migration increases and diversifies as families are affected by HIV/AIDS. The preliminary research in Malawi revealed that 58 percent of children from Mpando and 58 percent from Ndirande had moved at least once. In Lesotho, 50 percent of Maseru children and 31 percent of Tlali children had also moved. Of the reasons cited for migration, sickness/death accounted for 22 percent of rural reasons and 10 percent of urban reasons in Malawi and 6 percent and 4 percent, respectively, in Lesotho. In both rural locations, witchcraft, which is sometimes viewed as a cause of sickness, featured as a reason for migration ( 5 percent in Mpando and 7 percent in Tlali). Sickness/death was also cited as a reason for other children moving into the household (18 percent in urban and 20 percent in rural Malawi, and 6 percent and 17 percent, respectively, in Lesotho). Reasons for migration that might be indirectly related to AIDS, such as poverty, employment-seeking, or to help relatives, also featured highly. ${ }^{9}$

Detailed qualitative research revealed that young migrants leave their households for four main reasons, which may be exacerbated by AIDS: caring for sick relatives; the death of one or both parents; increased poverty due to illness/death in the family; and the remarriage of widowed parents. With respect to caring for a sick relative, children not only move to take on the responsibility of care but may also take on extra work burdens within the home. This was the case for Motselisi ${ }^{10}$ from Maseru. Her story revealed that she is currently living with her very sick aunt, helping to care for her and carrying out domestic duties. Previously, her aunt was providing for them, but she can no longer work. This affects Motselisi further, as reduced household income means that there is no money to pay for her school fees next term, which will 
Young $L$ and Ansell N (2003) 'Fluid households, complex families: the impacts of children's migration as a response to HIVIAIDS in southern Africa' The Professional Geographer 55(4) 464-479

force her to drop out of school. Children in situations like Motselisi's participate in a range of caring duties similar to those found by Robson (2000) in Zimbabwe, including cooking,

cleaning, administering medicine, and bathing and feeding the patient.

Relatively few children who participated in the research were young carers, however. More of those who participated had moved because of parental death. Brenda was from Salima. Her mother died soon after her father, and Brenda went to live with her elder sister and brotherin-law in Ndirande, Blantyre. Not long later, Brenda’s baby sister fell sick. She recalls how the baby had sores all over her face before she died. Now Brenda’s brother-in-law has lost his job, and the family is experiencing financial problems, which may further affect Brenda.

In other cases, the death of a parent resulted in children leaving the extended family altogether and moving to orphanages, onto the streets, or into employment. This form of household dispersal was generally related to poverty in the family, because there were insufficient resources to provide for surviving children. This poverty was sometimes related to abandonment by a surviving parent due to remarriage or mistreatment of the child by relatives.

\section{[Au: mistreatment of the child, or of the parent?]}

Whether moving to care for a sick relative, because of parental death, or due to AIDSrelated poverty, and whether moving into other households, into orphanages, or onto the streets, children were affected by a variety of associated impacts related to "belonging” and forming new relationships. The remainder of this article considers this in relation to the different ways in which young migrants are incorporated into new households. It also explores two further processes of household fragmentation affected by children's AIDS-related migration: multiple moves and sibling separation. 
Young $L$ and Ansell N (2003) 'Fluid households, complex families: the impacts of children's migration as a response to HIVIAIDS in southern Africa' The Professional Geographer 55(4) 464-479

\section{Re-forming the "Family": Children's Incorporation into New Households}

Although complex migrations associated with sickness and death result in fragmentation and reforming of extended family households, it is widely accepted across southern Africa that the extended family is the best provider of orphan care (Munthali and Ali 2000). This research highlighted many instances of appropriate care for children in this context, care that allows for social and cultural ties to be maintained and for children to grow up in family situations (MOGYCS and UNICEF 1999; UNICEF 1999; Grainger, Webb, and Elliott 2001). In such cases, the fragmentation process for children was eased following the death of a parent.

After the death of their parents they were very sad and disappointed; they were not happy. They had to spend a lot of days without being happy until we were able to take them here, and then they were able to begin to relax when they came here. (Mpando uncle)

Despite this, and as Urassa and colleagues (1997) note in relation to foster children, children are incorporated into "new" households in different ways, depending on how households treat the children they receive or on the expectations they have regarding the children's roles within the family and household. [Au: are scare quotes needed here? They are used on this term somewhat inconsistently below, although they are employed more often than not. I think they can be removed from 'new' throughout] With respect to young migrants in Lesotho and Malawi, several forms of incorporation were identified relating to the coping strategies employed by extended family groups following the breakdown of a particular household. 
Young $L$ and Ansell N (2003) 'Fluid households, complex families: the impacts of children's migration as a response to HIVIAIDS in southern Africa' The Professional Geographer 55(4) 464-479

"Adopted" Into the Household as Members of the Family Unit

Although the large numbers of orphans caused by AIDS is stretching the resources of support systems, the extended family remains the primary receiver of children (Cohen 2000). The care and attention children receive enables them to integrate into their "new” family units, becoming "adopted" as equal members of the household. Relatives may view this adoption process as a way of facilitating children's coming to terms with parental loss and becoming part of another family unit.

They still lived at the parents' home after the death of their parents, and then last year they came here. It was very difficult for them to live alone, as they were still very young. They didn’t have any food and good parental care and guidance....When they lived there I could see they were very lonely and missed their parents a lot, but now they are here, I love them, and I can see that they interact with other children now. (Maseru grandmother) [Au: when you do not specify focus group or storyboard, is it accurate to assume that the source of a quote is an interview? yes]

Adopted children sometimes see their incorporation into "new" households in this positive a manner. One group discussion with Tlali boys illustrated that in some instances, they feel so accepted into their new household that they quickly develop a sense of belonging to their new family unit: "My stay in this new place [uncle’s home] is still pleasant; it’s like I am still at home” (Tlali boys, focus group 1). 
Young $L$ and Ansell N (2003) 'Fluid households, complex families: the impacts of children's migration as a response to HIVIAIDS in southern Africa' The Professional Geographer 55(4) 464-479

Nonetheless, the fragmenting and re-forming of households through children’s migration can affect relationships in the new family, particularly if adoption is enforced rather than welcomed. Urassa and colleagues (1997) found that fostered children were more accepted by their extended family if their incorporation was due to fertility problems of the receivers, rather than to problems with the children's biological parents. Where migration was due to AIDS, children who moved to stay with relatives due to parental sickness/death did so because of obligations within the kin group, rather than due to someone’s desire for more children. In practice, this frequently resulted in young migrants being treated differently from other children in the household, or from how they were treated at home. In many instances, they felt discriminated against within the new family unit in favor of biological siblings, particularly if resources were scarce. Young migrants stated that they were given different foods, not provided with clothing, beaten, and overworked due to the sharing of scarce resources among a greater number of household members: "When you go to stay there [relative’s home], you may find that your cousins are jealous and you eat different foods, as they are favored by their parents” (Ndirande girls, focus group 3). Foster and colleagues (1995) note that older siblings sometimes accept children into their households. This is usually as a sibling, however, rather than as a child. Under such circumstances, adopted children often feel they receive inadequate care: "[I live with my brother now] and I don't get proper discipline” (Tlali girls, focus group 2).

Host families did not necessarily feel that they treated adopted children differently. Interviews with guardians demonstrated that relatives often tried to share what little they had among the whole family equally and to incorporate "new" siblings into their family by sharing out chores: “[W]hen there’s food, I share with everyone else, and I don’t say, “This is for my children only,” as my sister's children also have to eat” (Tlali aunt). Despite this, the re-forming 
Young L and Ansell N (2003) 'Fluid households, complex families: the impacts of children's migration as a response to HIVIAIDS in southern Africa' The Professional Geographer 55(4) 464-479

of households with "new" children can still cause divisions in the family. Children may not want to share their resources, both financial and emotional, with "new” siblings who may need extra attention, particularly if they are coming to terms with parental death (Human Rights Watch 2001). Interviews with guardians revealed that receiving children into the home can affect relationships if the distribution of resources results in jealousy among household members.

There are quarrels in the family because my children think they have their parents, so they treat the one that came with no parents badly. So she is always saying that they are ill-treating her because she has no parents. They fight over the food, and as I am the old one, I have to settle their disputes and tell them not to quarrel. (Mpando aunt)

As an older person, you might think you are taking good care of the children, but among them there will be fights and divisions. Because they are from two different families, they fight, saying, "We came here first, so it’s our home, not yours.” (Maseru grandmother)

Divisions within newly formed households also occur between children and receiving guardians. Children's behavior may be a reaction to experiencing traumatic events, such as parental death. A grandmother in Tlali mentioned that her grandson, who had come to live with her after her daughter died, began stealing money from her. Another grandmother in Ndirande mentioned that her grandsons participated in disruptive activities after their AIDS-related migration by stealing and refusing to go to school. The boys subsequently received counseling 
Young $L$ and Ansell N (2003) 'Fluid households, complex families: the impacts of children's migration as a response to HIVIAIDS in southern Africa' The Professional Geographer 55(4) 464-479

through the local project office of the Church of Central Africa Presbyterian. They have begun to settle down, and will soon enroll in school again. Such cases highlight the need for emotional support to be given to both the children affected by the loss of a parent and the relatives receiving them into their home.

Incorporated Into the Household as Workers

Children are also incorporated into households as workers, rather than simply as members of the family. This is undertaken in several different ways. One coping strategy of families in times of stress, such as increasing sickness and death among productive members, is to seek waged labor (UNAIDS 1999; Hunter and Williamson c2000; Rugalema 2000). Under such circumstances, children may provide the only means of support for the family. This can cause the fragmentation of households, as children are sent to work in other places so that the family can receive remittances. Children are also incorporated into "new” households as workers in less distinct ways, such as being sent to care for a sick relative. Although this is not paid employment, the principle reason for migration is to undertake caring duties for other family members. Similarly, children may be incorporated as workers as well as adopted into a new household if they are given specific chores to carry out in order to pay for their keep.

This research identified a number of young migrants who were engaged in wage labor as a means of supporting their families. While interviewing guardians in Mpando, for example, it was discovered that Jane had taken her young daughter out of school and sent her to work as a housegirl in order to support the family. The household had received two younger grandchildren following the deaths of their parents, and Jane's husband had recently passed away. At 13, her youngest daughter was the only member of the household who could secure employment, 
Young $L$ and Ansell N (2003) 'Fluid households, complex families: the impacts of children's migration as a response to HIVIAIDS in southern Africa' The Professional Geographer 55(4) 464-479

although she dislikes being away from home. Jane says:

[My daughter] works to help her mother. She doesn't like it but because of our problems she has to do it. She earns 100 kwacha [equal to U.K.£1.00] as her monthly salary, which she shares with us. (Mpando grandmother)

The burden on children is not only financial and physical, but also emotional. Some children migrate from their original household specifically to care for sick relatives. For example, Mafa, who was living with his aunt, was sent to another part of Maseru to care for his father. He mentions the pain he felt having to undertake caring duties and at the same time watch his father's condition deteriorate. He says:

Living with my sick father was a difficult and painful time for me, as I wanted my father to get well so that he could help me with the things I needed for school. I used to wash, bathe my father and put on his clothes for him, take him to hospital and give him his medicine...My father died in 1996 from TB. It upsets me to talk about my father’s death even now. (Maseru boy, aged 17, storyboard)

The impact of caring for a sick relative is felt in many aspects of children's lives, and little support or provision to continue with their own routines, such as attending school, appears to be available to children who are taking on the role of home-based care. No children who participated in storyboards and focus-group discussions mentioned support other than from their extended families. 
Young $L$ and Ansell N (2003) 'Fluid households, complex families: the impacts of children's migration as a response to HIVIAIDS in southern Africa' The Professional Geographer 55(4) 464-479

Although children are sent to other households as workers as a coping strategy of the extended family, their incorporation into relatives' families following the death of a parent may also be conditional. Children who join "new” families are sometimes given domestic chores or hired out in "return” for staying with their relatives (Kalemba 1998; NGO Coalition for the Rights of the Child 2000). The children's discussions revealed that this is particularly the case when family resources are stretched to accommodate new additions.

In my old place I did not get scolded. I was loved...[Now I live with my grandmother and]....I am scolded and I am beaten. I am beaten the whole day...It’s said, “Work! Plough!” (Tlali boys, focus group 4)

Such situations occur because children have ended up living with aging grandparents or relatives who lack the financial resources to provide for them properly. Of the guardians of orphaned children who were interviewed, thirty-four out of forty were grandparents caring for their grandchildren. Rather than being cared for by their children in old age, many grandparents are now finding that they have to begin again as parents when their children pass away. As Fanny, a grandmother in Mpando states, "It was difficult [for me to take in these children], as I am already old and I have no power to earn a living to help these little ones.” This often means that the grandchildren end up supporting the family by taking on extra chores or helping their grandparents to earn a living by selling foods or working in markets.

\section{Alternative Families on the Street and in Orphanages}

In some instances, the re-forming of households through children's migration takes place in an 
Young L and Ansell N (2003) 'Fluid households, complex families: the impacts of children's migration as a response to HIVIAIDS in southern Africa' The Professional Geographer 55(4) 464-479

unconventional way, with children going to the streets or orphanages. Here, the sense of "belonging" is still important: to be accepted into a different type of family formation on the street, children may adopt new behaviors. This is highlighted by an extract from Kondwani's storyboard of how he engaged with street life.

When I came to the streets I started smoking and beating others. One of the older street kids sent me to buy cigarettes for him. When I came back, he told me I had to smoke it first, so that is how I got the habit of smoking. I had to smoke to be with them. (Blantyre street kid, aged 15, storyboard)

The incorporation of children into alternative "families" means that they can become detached from their families and communities.

I will never go back to the way my life used to be. I am happy [here]. If you go back you end up not doing anything and just sitting at home. Some of us might be sent to initiation schools, or we could have been married by now. (Lesotho children's home, focus group) [Au: would it be useful for your readers to know what an initiation school is?]

Many children's homes in both Malawi and Lesotho now recognize the importance of keeping family ties, and children are encouraged to visit their relatives as often as possible. At a children's home in Blantyre, Malawi, the children stay with their relatives every weekend and holiday. Once they finish primary school, they return to live with their relatives, although the 
Young L and Ansell N (2003) 'Fluid households, complex families: the impacts of children's migration as a response to HIVIAIDS in southern Africa' The Professional Geographer 55(4) 464-479

children's home still provides financial assistance to ensure they continue with their education (Interview, Sister Melanie, Malawi children’s home).

Summary [Au: this paragraph appears to summarize the entire section thus far on "Reforming the 'Family'”, not just the subsection to which it was attached. Would separating it with a heading, either this one or one of your choosing, work for you? It's not really a summary. Although it refers to the entire section, I don't think it needs its own subheading]

This section has illustrated that children are incorporated into new households in very different ways. However, these modes of incorporation are not necessarily mutually exclusive. Children may be adopted by family members, yet be required to undertake chores in return for staying in the household. For example, one aged aunt from Tlali adopted her niece Nthabiseng after the death of Nthabiseng's parents, both to fulfill her obligations as a close family relative and to have Nthabiseng to help her in the house. Similarly, street children, employed working children, and children residing in orphanages may be simultaneously incorporated into more than one household as they return to their relatives' homes during holidays or at weekends. This demonstrates the complexity of children's relationships to their households and identifies that their migration is not a singular process.

\section{Multiple Moves}

The clustering of HIV/AIDS related-illnesses among families and communities (Foster et al. 1995; Nko et al. 2000) means households are often involved in further fragmentation as "new" carers fall sick or pass away or children are forced into alternative forms of employment to support the family. This results in some children engaging in multiple moves. A constant flux of 
Young $L$ and Ansell N (2003) 'Fluid households, complex families: the impacts of children's migration as a response to HIVIAIDS in southern Africa' The Professional Geographer 55(4) 464-479

fluid family units exists, exacerbated by the impact of HIV/AIDS.

The story of Annie from Ndirande reveals how she engaged in multiple migrations as sickness and death afflicted her extended family. Initially, she went to care for her sick grandmother. Soon after her grandmother recovered, her father fell sick, and she had to undertake caring duties for him. Not only was she bearing part of the burden of care, but she also states that she felt very sad because he was the only one working and able to help the family. After the death of her father, she moved again, this time returning to stay with her mother. However, loss of remittances from her father’s employment resulted in the household being impoverished. Annie then had to move again, this time being sent to live with her uncle to help him with housework and reduce the burden on her immediate family unit. This story illustrates the complexity of fragmentation, as households in the extended family function together across space as a support mechanism for the whole family. If one household breaks down, this affects others, resulting in the reorganization of family members in new household forms. Annie’s story further highlights the important role children play in the coping strategies of AIDS-afflicted families, and how this is played out in a series of independent migrations between extended family households.

Multiple moves are also prompted by situations of poverty, particularly for those children living in orphanages or on the streets. The clustering of HIV infections often results in some households receiving children from several families. Although children may initially go to live with relatives, they may find that there are not enough resources to support extra members. In both Malawi and Lesotho, this results in increasing fragmentation as children leave their extended family network to go onto the streets or into orphanages. Although extended families are willing to accept orphaned children they are ultimately unable to fully provide appropriate 
Young $L$ and Ansell N (2003) 'Fluid households, complex families: the impacts of children's migration as a response to HIVIAIDS in southern Africa' The Professional Geographer 55(4) 464-479

care and support.

When my father and mother died, I lived with my uncle. Then my uncle also got sick and died. So I went to live with my granny. I saw that life was tough living with my granny. She could not manage to send me to school; it was I alone who went to work in the garden because my granny was too old [so I came to the streets]. (Malawi street kids, focus group)

I came here after my parents died...because my aunt had a lot of children and she could not support us all... (Lesotho children's home, focus group)

The impact of HIV/AIDS on household fragmentation demonstrates the difficulties families encounter in supporting increasing numbers of orphans. Another consequence of extended families' inability to support large numbers of orphaned children is a further form of household fragmentation. The allocation of siblings to different relatives is an attempt to spread the burden of orphan care and reduce the need for subsequent migrations.

\section{Splitting of Households: Sibling Separation}

Corinne Grainger, Douglas Webb, and Lyn Elliott (2001) note that sibling dispersal is not the preferred choice of extended families. Despite this, the fragmentation of sibling groups does occur. Children are sometimes split among relatives at funerals, as it is economically difficult for one relative to care for a whole group of siblings. Focus groups revealed that children are rarely involved in these discussions, because it is the relatives who must decide whether they can afford 
Young L and Ansell N (2003) 'Fluid households, complex families: the impacts of children's migration as a response to HIVIAIDS in southern Africa' The Professional Geographer 55(4) 464-479

to care for the children. Children themselves suggested that children who are in need cannot impose their views on where or with whom they would like to live. In some instances, children are separated from their siblings by being placed in different households but live in close proximity to each other, making frequent visits possible. Interviews with guardians suggested that this enables families to care adequately for a large group of orphans, yet still foster close family relations. Some children, however, find that they are split from their siblings across large distances and unable to maintain such links, thereby losing not only their parents but also the support of the rest of their siblings: "Like what happened to me, when we were left behind [after the death of our parents], they [relatives] just took us to live in separate households” (Ndirande boys, focus group 2).

Through her storyboard, Mpho illustrates the difficulties sibling separation places on children who are moved from their home community.

This is my house in Khubetsoana where I moved to live with my cousins after my mother died. My little sister [doesn't live here]; she stays with my uncle, as they thought my cousins wouldn’t be able to care for her. I found it difficult [to be separated from her] because we were close and we had always lived together. Since my mum died, I can only go to see her at my uncle’s on weekends. (Maseru girl, aged 12, storyboard)

Sometimes the distances are too great for regular contact between siblings. In Lesotho, Matseliso, aged 11, had been taken from Teyateyaneng to live with her aged grandmother in Tlali after the funeral of her father. The rest of her siblings remained in Teyateyaneng with other 
Young $L$ and Ansell N (2003) 'Fluid households, complex families: the impacts of children's migration as a response to HIVIAIDS in southern Africa' The Professional Geographer 55(4) 464-479

relatives, and now she is unable to visit them, as her grandmother cannot afford the cost of transport. In such instances, the isolation felt from moving to a new place is increased as children lose not only their parents but also their home and family. This can be illustrated further by Richard's storyboard. After his parents died, his siblings were split among relatives and he was taken from Mpando, in Malawi, to live with his elder sister, who was married and living in Mozambique. The rest of his siblings remained behind with other relatives. As he had moved far away, he was unable to visit them. This affected him greatly.

It was sad leaving my siblings behind, as I knew I had left them in trouble. I was staying well in Mozambique, so I forgot that I had no mother, but what remained in my mind was how my siblings were surviving. (Mpando boy, storyboard)

Often, conflict within extended families magnifies the burden placed on children. Some stories mention that relatives fight over whom children should remain with after their parents have passed away. This not only results in sibling separation but also often reduces the possibility for contact between siblings if their relatives do not have good relations. During one interview in Maseru, a grandmother mentioned how her daughter was disliked by her in-laws. After her death, this resulted in the children being split among their grandparents, with the paternal grandmother taking care of her grandson. He is not allowed to visit his sister or maternal grandmother, and this has caused problems, as his sister misses him.

In virtually all of the interviews, poverty—particularly focused on providing food, clothing, and school fees—was highlighted as the main worry adult carers had regarding receiving extra children into their homes. This was also the main reason why children were 
Young L and Ansell N (2003) 'Fluid households, complex families: the impacts of children's migration as a response to HIVIAIDS in southern Africa' The Professional Geographer 55(4) 464-479

separated from their siblings. Increasing poverty associated with HIV/AIDS (Lyons 1999;

Harper and Marcus 2000) means families can no longer care for all orphans in the extended

family. This type of fragmentation means some children end up in institutionalized care.

Orphanages also sometimes separate children from their siblings because of strict rules regarding admittance age. For example, the discussion with children at a Malawian children's home revealed that only some siblings are taken into care, while others remain in the village:

I always think about my siblings I left at home in the village because I left them in poverty and I don't know what they think about me. (Malawi children’s home, focus group)

I wished that my sisters were here, but due to the rule which was imposed here saying that only the younger ones have to come here, not the bigger ones, I accepted that rule. (Malawi children’s home, focus group)

\section{Conclusion}

Children's migration, both as a coping mechanism and support system, comprises one aspect of the increasing fragmentation and rejoining of households as children engage in survival strategies for the benefit of the wider family. They move to help relatives, receive support themselves, and engage in paid work to support the household. This article has highlighted the fact that migration as a process of household fragmentation is not always singular, with children engaging in multiple moves or sibling groups split among several households, causing further dispersal. 
Young L and Ansell N (2003) 'Fluid households, complex families: the impacts of children's migration as a response to HIVIAIDS in southern Africa' The Professional Geographer 55(4) 464-479

Children's migration as a response to HIV/AIDS does appear to affect families and households as they break up and rejoin over space. This affects the relationships that exist within households, as new children are brought in or dispersed to live elsewhere. The result is a complex process of movement, with notions of “belonging," formed through relationships with particular members of the family in particular households, dismantled and re-created as children migrate. The extended family system in southern Africa is now witnessing such complex forms of households and families in light of the AIDS epidemic. 
Young L and Ansell N (2003) 'Fluid households, complex families: the impacts of children's migration as a response to HIVIAIDS in southern Africa' The Professional Geographer 55(4) 464-479

\section{Acknowledgments}

This research was funded by the UK Department for International Development (DFID). DFID

supports policies, programs, and projects to promote international development. DFID provided funds for this study as part of that objective, but the views and opinions expressed herein are those of the authors alone. The authors would like to thank three anonymous referees for their comments on an earlier draft of this article. Thanks to Motselisi Motsieloa in Lesotho and Lumbani Pete and Lloyd Chitera in Malawi, for research assistance in the field, the Institute of Southern African Studies, National University of Lesotho and the Department of Geography, Chancellor College, University of Malawi, for institutional support, and also to those who participated in the research. 
Young L and Ansell N (2003) 'Fluid households, complex families: the impacts of children's migration as a response to HIVIAIDS in southern Africa' The Professional Geographer 55(4) 464-479

\section{Literature Cited}

Agarwal, Bina. 1990. Social security and the family: Coping with seasonality and calamity in rural India. Journal of Peasant Studies 17 (3): 341-412.

Ali, Sandra. 1998. Community perceptions of orphan care in Malawi. Paper presented at the Southern African Conference on Raising the Orphan Generation, Pietermaritzburg, 12-19 June.

Ansell, Nicola, and Lorraine Young. 2002. Children's migration as a household/family strategy: Coping with AIDS in southern Africa. Submitted manuscript [Au: any publication update?]

BakamaNume, Bakama. 1996. A geography of AIDS: Spatial variation of AIDS infection in Uganda, 1987-1994. Occasional Paper, Department of Geography, Makerere University, Kampala. [Au: is this is a thesis or dissertation? Also, is name correct? yes]

Bandawe, Chiwoza R., and Johann Louw. 1997. The experience of family foster care in Malawi: A preliminary investigation. Child Welfare LXXVI (4): 535-47.

Barnett, Tony, and Piers Blaikie. 1992. AIDS in Africa: Its present and future impact. London: Belhaven.

Barnett, T., and A. Whiteside. 1999. HIV/AIDS in Africa: Implications for "development” and major policy implications. Standing Committee on University Studies on Africa InterUniversity Colloquium, University of East Anglia, Norwich, 5-8 September 1999. [Au: if this is a paper delivered at this colloquium, need date(s) of colloquium. Also, please spell out SCUSA and UEA here.]

Baylies, Carolyn. 2001. Precarious futures: The new demography of AIDS in Africa. Paper presented at conference on Africa’s Young Majority: Meanings, Victims, Actors, Centre 
Young $L$ and Ansell N (2003) 'Fluid households, complex families: the impacts of children's migration as a response to HIVIAIDS in southern Africa' The Professional Geographer 55(4) 464-479

of African Studies, University of Edinburgh, Edinburgh, 23-25 May.

Beer, C., A. Ross, and K. Tout. 1988. AIDS: The grandmothers' burden. In Fleming A ed The global impact of AIDS Liss, New York. [Au: need complete reference for source, including full title of book, page range of essay, and publisher.]

Bourdillon, M. F. C. 1999. The next generation. Paper delivered at Conference on AIDS, Livelihood, and Social Change in Africa, Wageningen, 15-16 April. http://www.kit.nl/ils/assets/images/paper_bourdillon.doc (last accessed 8 July 2003).

Camacho, Agnes Zenaida V. 1999. Family, child labour, and migration: Child domestic workers in metro Manila. Childhood 6 (1): 57-73.

Chanock, Martin. 1985. Law, custom, and social order: The colonial experience in Malawi and Zambia. Cambridge, UK: Cambridge University Press.

Cliff, A. D., and M. R. Smallman-Raynor. 1992. The AIDS pandemic: Global geographical patterns and local spatial processes. The Geographical Journal 158 (2): 182-98.

Cohen, Desmond. 2000. Poverty and HIV/AIDS in sub-Saharan Africa. United Nations Development Programme HIV and Development Programme issue paper no. 27. http://www.undp.org/hiv/publications/issues/english/issue27e.html (last accessed 8 July 2003).

Crush, Jonathan, Theresa Ulicki, Teke Tseane, and Elizabeth Jansen van Vuuren. 1999. Undermining labour: Migrancy and subcontracting in the South African gold-mining industry. Cape Town: Idasa.

Desmond, Chris, Karen Michael, and Jeff Gow. 2000. The hidden battle: HIV/AIDS in the household and community South African Journal of International Affairs 7 (2): 39-58.

Dodson, Belinda. 1998. Women on the move: Gender and cross-border migration to South 
Young $L$ and Ansell N (2003) 'Fluid households, complex families: the impacts of children's migration as a response to HIVIAIDS in southern Africa' The Professional Geographer 55(4) 464-479

Africa. Cape Town: Idasa.

Foster, Geoff, Choice Makufa, Roger Drew, and Etta Kralovec. 1997. Factors leading to the establishment of child-headed households: The case of Zimbabwe. Health Transition Review 7 (supplement 2): 155-68.

Foster, G., R. Shakespeare, F. Chinemana, H. Jackson, S. Gregson, C. Marange, and S. Mashumba. 1995. Orphan prevalence and extended family care in a peri-urban community in Zimbabwe. AIDS Care 7 (1): 3-17.

Grainger, Corinne, Douglas Webb, and Lyn Elliott. 2001. Children affected by HIV/AIDS: Rights and responsibilities in the developing world. London: Save the Children.

Harper, C., and R. Marcus. 2000. Child poverty in sub-Saharan Africa. London: Save the Children.

Human Rights Watch. 2001. In the shadow of death: HIV/AIDS and children's rights in Kenya. Human Rights Watch 13 (4[A]). http://www.hrw.org/reports/2001/kenya/kenya0701.PDF (last accessed 8 July 2003).

Hunter, Susan, and John Williamson. 2000. Children on the brink: Executive summary: Updated estimates and recommendations for intervention. Washington, DC: USAID. http://www.dec.org/pdf_docs/PNACJ284.pdf (last accessed 8 July 2003).

Hunter, Susan, and John Williamson. c2000. Children on the brink: strategies to support a generation isolated by HIV/AIDS. Washington, DC: USAID. [Au: since I wasn't sure sure what “c2000" signifies, I checked the USAID website. It lists a publication by these authors and this title at http://www.dec.org/pdf_docs/PNACC519.pdf, but the publication date is 1997. Is this the correct source? yes]

ILO. 1998. Internal and external migration and youth unemployment in Lesotho. Maseru, 
Young $L$ and Ansell N (2003) 'Fluid households, complex families: the impacts of children's migration as a response to HIVIAIDS in southern Africa' The Professional Geographer 55(4) 464-479

Lesotho: International Labour Organization. [Au: please spell out ILO here.]

Jones, S. 1993. Assaulting childhood: Children's experiences of migrancy and hostel life in South Africa. Johannesburg: Witwatersrand University Press.

Kalemba, Asau. 1998. The development of an orphans policy and programming in Malawi: A case study. Paper presented at the Southern African Conference on Raising the Orphan Generation, Pietermaritzburg, 12-19 June.

Kimane, Itumaleng, and Akim J. Mturi. 2001. Rapidly assessing children at work in Lesotho.

Vol. 1, Context and overview of findings. Government of Lesotho (with financial assistance from UNICEF), Maseru, Lesotho. [Au: need publisher and place of publication, or URL.]

Lyons, Miriam. 1999. The impact of HIV and AIDS on children, families, and communities:

Risks and realities of childhood during the HIV epidemic. United Nations Development Programme HIV and Development Programme issue paper no. 30. http://www.undp.org/hiv/publications/issues/english/issue30e.html (last accessed 8 July 2003).

McDonald, David A., ed. 2000. On borders: Perspectives on international migration in southern Africa. Kingston, ON: Southern African Migration Project.

McDowell, Christopher, and Arjan de Haan. 1997. Migration and sustainable livelihoods: A critical review of the literature. Institute of Development Studies Working Paper. Brighton: IDS.

McKendrick, John H. 2001. Coming of age: Rethinking the role of children in population studies. International Journal of Population Geography 7:461-72.

Ministry of Gender, Youth and Community Services (MOGYCS) and the United Nations 
Young $L$ and Ansell N (2003) 'Fluid households, complex families: the impacts of children's migration as a response to HIVIAIDS in southern Africa' The Professional Geographer 55(4) 464-479

Children's Fund (UNICEF). 1999. Best practices on community-based care for orphans.

Lilongwe, Malawi: Ministry of Gender, Youth and Community Services.

Mobility and changing sexual behaviour. 1999. Position paper for Conference on AIDS,

Livelihood, and Social Change in Africa, Wageningen, 15-16 April.

http://www.kit.nl/ils/assets/images/Theme_Mobility-web.doc (last accessed 8 July 2003).

Munthali, Alister C., and Sandra Ali. 2000. Adaptive strategies and coping mechanisms: The

effect of HIV/AIDS on the informal social security system in Malawi. Lilongwe, Malawi:

National Economic Council, Government of Malawi.

Murray, Colin. 1981. Families divided: The impact of migrant labour in Lesotho. Cambridge,

UK: Cambridge University Press.

NGO Coalition for the Rights of the Child. 2000. 'Etsa letsete la kamoso, netefatsa litokelo tsa

ka': The state of children's rights in Lesotho/ Boema ba litokelo tsa bana Lesotho.

London: Save the Children UK. [Au: The Professional Geographer style requires that

the titles of works not in English be translated into English. Please provide a

translation for the title of this source. I can't translate the first part. the second bit of

sesotho is the translation of the English title. the publication is in both languages]

Nko, Soori, Betty Chiduo, Flora Wilson, Wences Msuya, and Gabriel Mwaluko. 2000. Tanzania:

AIDS care—Learning from experience. Review of African Political Economy 86:547-57.

Ntozi, James P. M. 1997. Effect of AIDS on children: The problem of orphans in Uganda.

Health Transition Review 7 (supplement): 23-40.

Robson, Elsbeth. 2000. Invisible carers: Young people in Zimbabwe’s home-based health care.

Area 32 (1): 59-70.

Rugalema, Gabriel. 2000. Coping or struggling? A journey into the impact of HIV/AIDS in 
Young $L$ and Ansell N (2003) 'Fluid households, complex families: the impacts of children's migration as a response to HIVIAIDS in southern Africa' The Professional Geographer 55(4) 464-479

southern Africa. Review of African Political Economy 86:537-45.

Sauerborn, R., A. Adams, and M. Hien. 1996. Household strategies to cope with the economic costs of illness. Social Science and Medicine 43 (3): 291-301.

Sporton, Deborah, David S. G. Thomas, and Jean Morrison. 1999. Outcomes of social and environmental change in the Kalahari of Botswana: The role of migration. Journal of Southern African Studies 25 (3): 441-59.

Townsend, Nicholas W. 1997. Men, migration, and households in Botswana: An exploration of connections over time and space. Journal of Southern African Studies 23 (3): 405-20.

UNAIDS. 1999. A review of household and community responses to the HIV/AIDS epidemic in the rural areas of southern Africa. Geneva: UNAIDS.

. 2000. AIDS epidemic update: December 2000. Geneva: UNAIDS/WHO.

- 2002. Report on the global HIV/AIDS epidemic. Geneva: UNAIDS.

UNAIDS, the United Nations Children’s Fund (UNICEF), and the Black Leadership Commission on AIDS (BLCA). 1999. Call to action for "children left behind" by AIDS. [Au: need publication information or URL for this source. http://www.unaids.org/publications/documents/children/young/orphanaction.doc] United Nations Children's Fund (UNICEF). 1999. Building systems of protection for children affected by HIV/AIDS in Lesotho: Report of an assessment of programming in Lesotho for families and children affected by HIV/AIDS. UNICEF, Maseru, Lesotho. [Au: need location of UNICEF office publishing this source or URL for source.]

Urassa, Mark, J. Ties Boerma, Raphael Isingo, Juliana Ngalula, Japheth Ng’weshemi, Basia Zaba, and Gabriel Mwaluko. 2001. The impact of HIV/AIDS on mortality and household mobility in rural Tanzania. AIDS 15:2017-23. 
Young $L$ and Ansell N (2003) 'Fluid households, complex families: the impacts of children's migration as a response to HIVIAIDS in southern Africa' The Professional Geographer 55(4) 464-479

Urassa, Mark, J. Ties Boerma, Japheth Ng'weshemi, Raphael Isingo, Dick Schapink, and Ysufu Kumogola. 1997. Orphanhood, child fostering, and the AIDS epidemic in rural Tanzania Health Transition Review 7 (supplement 2): 141-53.

Webb, Douglas. 1997. HIV and AIDS in Africa. London: Pluto.

White, Landeg. 1987. Magomero: Portrait of an African village. Cambridge, UK: Cambridge University Press.

Williams, Brian, Eleanor Gouws, Mark Lurie, and Jonathan Crush. 2002. Spaces of vulnerability: Migration and HIV/AIDS in South Africa. Cape Town: Idasa.

Young, Lorraine, and Nicola Ansell. 2002. Moving in the wake of AIDS: children's experiences of migration in Southern Africa. Submitted manuscript. [Au: any publication update?]

LORRAINE YOUNG lecturer, Department of Geography and Earth Sciences, Brunel University, Uxbridge, Middlesex UB8 3PH, UK. E-mail: lorraine.young@brunel.ac.uk.

NICOLA ANSELL lecturer, Department of Geography and Earth Sciences, Brunel University, Uxbridge, Middlesex UB8 3PH, UK. E-mail: nicola.ansell@brunel.ac.uk.

[Au: The Professional Geographer requires short biographies of all authors at the end of the reference section of each article. Please provide the following: position (both authors); department (Dr. Ansell); and a sentence about current research interests (both authors).] 
Young $L$ and Ansell N (2003) 'Fluid households, complex families: the impacts of children's migration as a response to HIVIAIDS in southern Africa' The Professional Geographer 55(4) 464-479 
Young $L$ and Ansell N (2003) 'Fluid households, complex families: the impacts of children's migration as a response to HIVIAIDS in southern Africa' The Professional Geographer 55(4) 464-479

\section{Notes}

${ }^{1}$ The term "coping strategy" is used here to refer to actions employed in response to crises, not to suggest that such actions are either successful or carefully planned (Ansell and Young forthcoming).

${ }^{2}$ Periods shorter than one month were discounted to exclude visits to relatives.

${ }^{3}$ The term "family unit" is used in this article to refer to the nuclear family unit of parents and children, regardless of whether they are part of a larger household unit.

${ }^{4}$ It must be noted that these figures are underrepresented, as they refer only to children under the age of 15 who have lost one or both parents.

${ }^{5}$ Urban and rural communities were selected to identify particular issues faced by children moving from urban to rural areas and vice versa. These issues are discussed in more detail elsewhere (Young and Ansell 2002).

${ }^{6}$ The research was confined to this age range to access children who had well-informed views regarding migration and had moved at least once.

${ }^{7}$ In Malawi, this involved children in standards 5 to 8 in primary school. In Lesotho, children from standards 5 to 7 in the primary school and form 1 of affiliated high schools participated in the research. [Au: will your readers

\section{know what you mean here by “standards”?]}

${ }^{8}$ For ethical and practical reasons, the research was not restricted to those children whose situations were demonstrably related to HIV/AIDS. Although cause of death was discussed, the stigma associated with HIV/AIDS meant that this was rarely cited as the cause of death. Given that two-thirds of orphans in Malawi and Lesotho are AIDS orphans (Hunter and Williamson 2000), the majority of the children involved in the stories related here will have been indirectly affected by AIDS.

${ }^{9}$ The qualitative research revealed that sometimes children's given reasons for migration, such as poverty or employment-seeking, were actually directly related to death in the family.

${ }^{10}$ To protect children's identities, all names used are pseudonyms. 